\title{
Glial Heterotopia of the Scalp in an Infant
}

\author{
Aditya Pratap Singh ${ }^{1},{ }^{*}$ Maryem Ansari ${ }^{2}$, Arun Kumar Gupta ${ }^{1}$, Ramesh Tanger $^{1}$, Vinay Mathur ${ }^{1}$ \\ 1 Department of Pediatric Surgery, SMS Medical College Jaipur, Rajasthan, India. \\ 2. Department of Pathology, SMS Medical College Jaipur, Rajasthan, India.
}

\author{
Correspondence*: Dr. Aditya Pratap Singh, Department of Pediatric Surgery, SMS Medical College Jaipur, Rajasthan, India. \\ E-mail: dr.adisms@gmail.com \\ (C) 2017, Singh et al, \\ Submitted: 05-06-2017 \\ Accepted: 02-08-2017 \\ Conflict of Interest: None \\ Source of Support: Nil
}

This is an open-access article distributed under the terms of the Creative Commons Attribution License, which permits unrestricted use, distribution, and reproduction in any medium, provided the original work is properly cited.

\section{DEAR SIR}

Scalp masses in children have a varied etiology. While many are associated with pathognomonic signs and can be diagnosed clinically. But few of them have a histological surprise [1]. We are presenting here a case of occipital swelling in the 4 months old male child that was clinically mistaken as dermoid.

A 4-month-old male infant presented with a painless scalp swelling $(3 \times 2 \mathrm{~cm})$ at the occipital region since birth. On examination, it was non-tender, soft, and non-compressible. The swelling was surrounded by a circle of long coarse hair. There was no impulse on crying and an underlying bony defect was not evident. There was history of single episode of the clear fluid discharge from the swelling. CT scan showed a midline, well circumscribed, extra cranial, heterogeneous swelling without the bony defect. The underlying intracranial structures were normal and separate from the extracranial mass lesion (Fig.1).

A differential diagnosis of a dermoid or an atretic encephalocele was thought. At surgery, the encapsulated mass was excised with an ellipse of the overlying skin. There was no connection seen with the intra cranial structures without any bony defect. Histopathological examination showed normal squamous lining with adnexal structures. In the deep dermis and subcutis, there is a focus of glial tissue, choroid plexus and nerves (Fig.2). These features confirmed the diagnosis of a glial heterotopia $(\mathrm{GH})$. At 1 month follow-up, the child is well, asymptomatic and there is no residuum or recurrence.

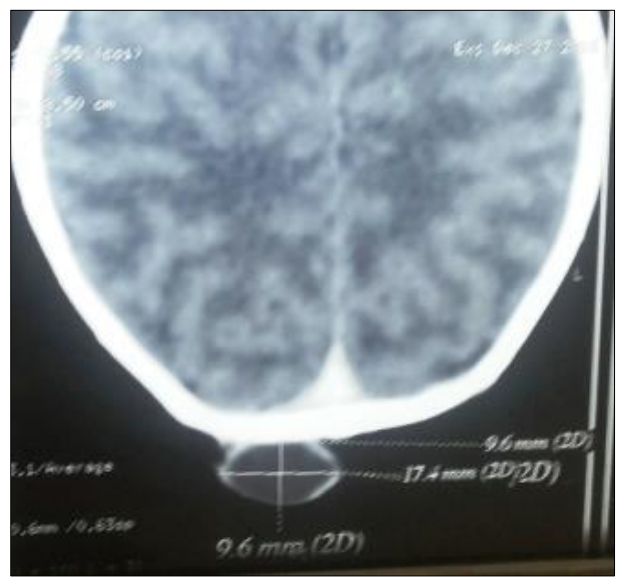

Figure 1: CT scan of the lesion.

Heterotopic neuroglial tissue represents normal brain tissue in an abnormal location away from the CNS. It is a rare congenital anomaly and the majority of these lesions are diagnosed at birth as bald, painless, soft nodules that proportionately increase with the growth of the child. Our case had also same presentation. Sometimes these bald nodules may be surrounded by a circle of long coarse hair (hair collar sign) and accompanied by a capillary stain [2]. It was also present in our case. 


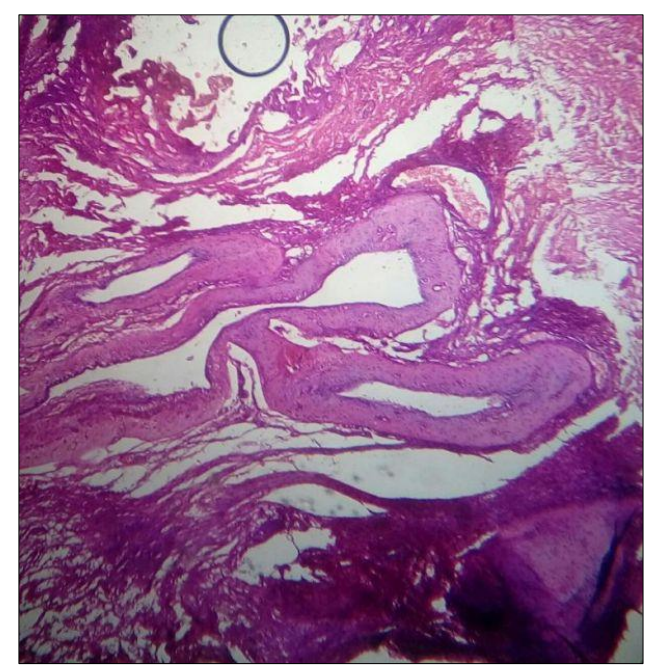

Figure 2: Histopathology showing glial tissue.

The most common location for heterotopic neuroglial tissue is in the base of nose, where it is traditionally but erroneously termed as Nasal Glioma. Other heterotopic sites include skin, palate, orbit, scalp, lung, etc. Glial heterotopias of head and neck are rare. MRI is helpful in determining its intracranial extension. The absence of a meningeal investment and intracranial communication distinguishes it from a typical encephalocele [3,4]. There was no intracranial communication in our case. Treatment is surgical excision. Diagnosis is usually confirmed on histopathology [3].

Consent: Authors have submitted signed consent form from legal guardians of the patient for use of clinical material in this manuscript. The Consent form is available with Editorial office.

Authors' Contribution: All authors contributed equal-ly in concept, literature review, and drafting of the manuscript and approved the final version of this manuscript.

\section{REFERENCES}

1. Lee CM Jr, McLaurin RL. Heterotopic brain tissue as an isolated embryonic rest. J Neurosurg. 1955;12:190-5.

2. Inchara YK, Rajalakshmi T, Das K. Glial heterotopia of the scalp. Indian J Pathol Microbiol. 2010;53:560-1.

3. Arikeri R, Pindicura K, Namala V, Penta R, Suggula R, Dandala SR, et al. Glial heterotopia in head and neck, single center experience of 5 cases. Int $J$ Res Med Sci. 2016;4:3009-12.

4. McGarr PL, Ramdial PK, Madaree A. Heterotopic brain tissue in scalp. Plast Reconstr Surg. 2001;107:497-500. 